\title{
РЕЖИМЫ ДЕНЕЖНО-КРЕДИТНОЙ ПОЛИТИКИ И МЕРЫ ЦЕНТРАЛЬНЫХ БАНКОВ В НОВОЙ ЭКОНОМИЧЕСКОЙ РЕАЛЬНОСТИ
}

\author{
(C) 2021 Савинов Олег Германович \\ кандидат экономических наук, доцент кафедры финансов и кредита \\ Самарский государственный экономический университет, Россия, Самара \\ E-mail:ogsvnv@gmail.com \\ (c) 2021 Савинова Надежда Григорьевна \\ кандидат экономических наук, доцент кафедры финансов и кредита \\ Самарский государственный экономический университет, Россия, Самара \\ E-mail: savnad@bk.ru \\ (c) 2021 Мясникова Анастасия Игоревна \\ студент \\ Самарский государственный экономический университет, Россия, Самара \\ E-mail:myasnikova99@bk.ru
}

Ухудшение финансовой стабильности во всех странах мира в 2019-2020 гг. потребовало принятия мер центральными банками. В статье раскрываются различные режимы денежно-кредитной политики, инструменты и меры, направленные центральными банками на восстановление экономики от макроэкономического шока в условиях пандемии коронавируса. Оцениваются экономические последствия резкого снижения спроса и предложения в период локдауна, влияние конъюнктуры нефтяного рынка на основные макроэкономические показатели российской экономики в кризисных ситуациях. Исследуется формирование новой экономической реальности и масштабный перелом финансовых трендов в мире в условиях комбинированного внешнего и внутреннего шока.

Ключевые слова: современная экономическая реальность, локдаун, режимы денежно-кредитной политики, меры центральных банков, финансовая стабильность.

В сложившихся неблагоприятных экономических условиях, обусловленных эпидемиологической обстановкой в мире и локдауном, усиливается роль денежно-кредитной политики государства в обеспечении финансовой стабильности. Наряду с другими глобальными факторами пандемия коронавируса оказала существенное влияние на снижение макроэкономических показателей во всех странах мира.

Современные экономические и финансовые условия характеризуются масштабным переломом трендов во всем мире, вызванных пандемией коронавируса. По мнению экономистов, внезапная остановка во многих сферах деятельности привела экономику и ее финансовую систему в состояние шока [4; 146-170]. Экономические последствия пандемии проявились в одновременном резком сжатии спроса и предложения, а также ухудшении финансовой стабильности. Режим локдауна оказал влияние на резкое сокращение спроса на многие товары и услуги, особенно в таких секторах экономики, как торговля, общественное питание, туризм, транспорт. Ограничения в производственной отрасли и в строительстве привели к сокращению денежных потоков [3; 177-181]. Снижение реальных денежных доходов граждан и рентабельности организаций отразилось на росте просроченной задолженности по банковским корпоративным и потребительским кредитам [2; 140]. Неопределенность в условиях развития пандемии в мире оказала влияние на фондовые рынки, рынок долларового финансирования.

Последствия снижения экономической активности и ухудшения финансовой стабильности оцениваются во всем мире для принятия мер в рамках денежно-кредитной политики [6]. В странах с развитой экономикой меры денежнокредитной политики в начале были направлены на стабилизацию финансовых рынков и предотвращение перерастания пандемии в новый финансовый кризис. Основными инструментами 
такого рода интервенций были покупка государственных активов и обеспечение ликвидности на льготных условиях. В ситуации ухудшения ликвидности в частном и корпоративном секторах экономики центральными банками были приняты меры по смягчению денежно-кредитных условий [1; 86-89]. Несмотря на рост кредитного риска, частному сектору для поддержания потребительского спроса предоставлялись кредиты на более привлекательных условиях.

В странах Еврозоны денежно - кредитная политика была направлена на смягчение финансовых условий и ориентирована центральными банками на внутренние цели, прежде всего, на поддержку совокупного спроса, несмотря на значительный отток капитала и резкое обесценивание валюты. В отдельных странах центральные банки рискнули дополнительно снизить процентные ставки и расширить программы покупки активов.

Макроэкономические показатели и совокупный спрос в странах с развивающейся экономикой снизились на более низкий уровень. Действия центральных банков были направлены на сдерживание роста курса доллара США и нейтрализацию ситуации на мировых финансовых рынках [6].

Пандемия стала общим, массовым потрясением для всей мировой экономики. Однако факторы уязвимости в различных странах различались, что было обусловлено структурными особенностями реального и финансового секторов экономики. В отличие от финансового кризиса 2007-2009 гг., который начался с проблем на финансовых рынках и распространился на реальную экономику, передача шока в условиях пандемии осуществлялась в обратном направлении. Жесткие меры сдерживания реальной экономики привели к экономическому застою и распространились на финансовый сектор. В результате рынки корпоративных ценных бумаг, а также рынки ценных бумаг, обеспеченных активами и ипотекой, практически прекратили функционировать. Резко упали цены на акции, выросла волатильность широкого спектра активов.

Российская экономика помимо глобального шока, испытанного от пандемии коронавируса, находилась под воздействием следующих проблем, усугубляющих масштабы финансовой нестабильности:

- падения мировых цен на нефть, сокращения нефтегазового экспорта и, как следствие, снижения экспортных доходов;

- внешних санкций и сложной геополитической обстановки, ограничивающих доступ к международным финансовым рынкам и зарубежным займам, а также влияющих на отток капитала;

- девальвации российского рубля из-за снижения курса национальной валюты, что привело к повышению цен на импорт и снижению покупательной способности российских граждан, потребляющих значительную долю импортных товаров.

Глобальные факторы, в том числе пандемия коронавируса, привели к масштабным изменениям в реальном секторе экономики. О масштабе проблем в кризисных ситуациях для российской экономики свидетельствуют следующие макроэкономические показатели (табл. 1).

Замедление мировой экономики сопровождалось снижением поставок нефти и газа и одновременным снижением цен на мировом рынке. Внешний шок распространился на весь спектр российского сырьевого экспорта, что оказало влияние на снижение темпов прироста ВВП. Недостаточный приток валютной выручки сказывался на снижении финансирования импорта и волатильности курса иностранной

Таблица 1. Основные макроэкономические показатели российской экономики в кризисных ситуациях

\begin{tabular}{|l|c|c|c|c|c|c|}
\hline \multicolumn{1}{|c|}{ Показатель } & 2008 & 2009 & 2013 & 2014 & 2019 & 2020 \\
\hline Среднегодовая цена нефти Urals, долл/барр. & 97,7 & 61,9 & 108,8 & 98,9 & 63,3 & 42,4 \\
\hline Прирост ВВП,\% & 5,2 & $-7,8$ & 1,8 & 0,7 & 1,3 & $-3,8$ \\
\hline Инфляция,\% & 13,3 & 8,8 & 6,5 & 11,4 & 3,1 & 4,9 \\
\hline Процентная ставка Банка России,\% на начало года & 13,0 & 8,75 & 5,5 & 17,0 & 7,75 & 6,25 \\
\hline Нефтегазовый экспорт, млрд. долл. & 326,3 & 203,4 & 355,7 & 330,2 & 237,8 & 97,6 \\
\hline Золотовалютные резервы, млрд. долл. & 427,1 & 439,0 & 509,6 & 385,5 & 468,5 & 556,0 \\
\hline Чистый вывоз (отток) капитала за год, млрд. долл. & 133,6 & 57,5 & 61,0 & 151,5 & 22,1 & 47,8 \\
\hline Курс, руб/долл на начало года & 24,8 & 31,7 & 31,8 & 38,0 & 69,31 & 74,12 \\
\hline Прирост денежной массы М2,\% & 0,8 & 17,7 & 14,6 & 2,2 & 9,7 & 13,5 \\
\hline
\end{tabular}


валюты. В кризисных ситуациях 2013-2014 гг. и 2019-2020 гг. на состояние макроэкономических показателей российской экспортно-сырьевой экономики и замедление экономического роста значительное влияние оказывало снижение нефтегазовых доходов, внутренней инвестиционной активности, что привело к обесценению национальной валюты. По сравнению с 2013 годом курс доллара США вырос в 2,3 раз. Санкции, сокращение экспортных доходов и отток капитала усугубляют масштабы экономических проблем. В результате снижения внешнего потребления нефти, а также падения внутреннего потребительского спроса российская экономика одновременно подверглась двойному шоку. Потенциал повышения покупательной способности населения за счет кредитов был исчерпан. Снизились объемы кредитования реального сектора экономики [1; 89].

Волатильность инфляции, процентных ставок и обесценение национальной валюты стали источниками неопределенности. Решения Банка России относительно ключевой ставки в 2020-2021 гг. были разнонаправленными и во многом обусловлены ожидаемым уровнем инфляции. Волатильность курса иностранной валюты в условиях профицита ликвидности способствовала росту спекулятивных операций кредитных организаций по покупке и продаже иностранной валюты, росту доходов и расходов от их проведения до 70\%. Волатильность инфляции оказывала влияние на ухудшение ожиданий граждан, уменьшение процентных ставок - на отток вкладов и покупку недвижимости. Повышенный спрос не недвижимость нивелировал снижение процентных ставок по ипотечным кредитам.

В открытых экономиках развивающихся стран центральным банкам становится все сложнее проводить независимую денежнокредитную политику, поддерживать приток капитала, регулировать валютный курс, процентную ставку и денежную массу [7]. Выбор адекватного режима денежно-кредитной поли- тики и инструментов ее реализации во многом определялся состоянием национальной экономики (табл. 2). Основными инструментами денежно-кредитной политики различных государств являются: процентные ставки, резервные требования, рефинансирование и депозитные операции, операции на открытом рынке и валютные интервенции.

Учитывая, что процентные ставки в развитых странах близки к нулю, меры центральных банков по стимулированию кредитной активности ограничены. Наиболее значимым инструментом Федеральной резервной системы (ФРС) США являются операции на открытом рынке. В 2019 году 10 стран, включая Россию, осуществляли таргетирование инфляции, применяя свободно плавающий курс. Большинство стран (25) в целях снижения волатильности и управления валютным курсом применяли режим плавающего курса. ФРС и Европейский центральный банк (ЕЦБ) стабильно удерживали низкую инфляцию на уровне 2,3 и 0,3\% соответственно. Процентная ставка ФРС и ЕЦБ составляла 0,25\% и 0,05\% соответственно. Отдельные страны в рамках заранее объявленных интервенций накапливают резервы (Албания), покупают или продают иностранную валюту для формирования государственного пенсионного фонда (Норвегия). В России объем интервенций основывается на покупке Министерством финансов через Банк России иностранной валюты на сумму дополнительных нефтегазовых доходов, полученных при продаже нефти марка Urals по цене свыше 40 долларов США за баррель. При цене ниже данного уровня Министерство финансов осуществляет продажу иностранной валюты. Данные операции оказывают влияние на денежный рынок, изменение ликвидности в банковском секторе. В период девальвационного давления (август-декабрь 2018 года) Банк России приостанавливал покупку иностранной валюты.

Экономические, финансовые, валютные, банковские кризисы оказывали влияние на трансформацию режимов таргетирования

Таблица 2. Основные режимы денежно-кредитной политики в странах с таргетированием инфляции и монетарным таргетированием [5]

\begin{tabular}{|l|c|c|c|}
\hline \multicolumn{1}{|c|}{ Курсовой режим (количество стран) } & $\begin{array}{c}\text { Монетарное таргети- } \\
\text { рование (26) }\end{array}$ & $\begin{array}{c}\text { Таргетирование } \\
\text { инфляции (41) }\end{array}$ & Другое (45) \\
\hline Плавающий курс (35) & 5 & 25 & 5 \\
\hline Свободно плавающий курс (31) & & 10 & 21 \\
\hline
\end{tabular}

Источник: Annual Report on Exchange rate arrangements and exchange rate restrictions. International Monetary Fund, 2019, imf.org 
денежно-кредитной политики. Развивающиеся страны подвергались более разрушительному воздействию кризисов, что обусловлено высоким уровнем инфляции, низкой устойчивостью национальной валюты, слабым развитием финансовых рынков, зависимостью от мирового рынка капитала.

В рамках исследований МВФ отмечены следующие последствия Covid-19 [5]:

1. Деструкция рынков активов с фиксированным доходом. На казначейском рынке США проявилась тенденция распродажи и резкого увеличения долгосрочной доходности.

2. Сокращение потоков денежного капитала в развивающихся странах привело к снижению частного и государственного внешнего финансирования, обесцениванию валюты и дальнейшему ужесточению финансовых условий. Рынки облигаций в национальной валюте были распроданы, а доходность государственных облигаций в нескольких странах резко выросла.

Банковский сектор напрямую не был затронут, однако проблемы роста просроченной задолженности по мере ухудшения финансового положения корпоративных и частных клиентов носят отложенный характер.

Реакция центральных банков на локдаун и принятые меры в рамках денежно-кредитной политики в странах с развитой и развивающейся экономикой были разными по масштабам и глубине вмешательства [6]. Для смягчения спада экономической активности и обеспечения бесперебойного функционирования финансового сектора первоначально центральными банками были приняты меры по процентной политике и расширению кредитов рефинансирования. Эти меры позволили банкам поддержать ликвидность и обеспечить кредитными ресурсами частный и корпоративный секторы. В то же время центральные банки объявили о проведении валютных интервенций с целью ослабления валютного давления и снижения волатильно- сти валютного курса. Постепенно центральные банки активизировали покупку активов. Если на начальном этапе кризиса центральные банки сосредоточились на улучшении функционирования рынка, то на более поздних этапах акцент был смещен на финансирование как частного, так и государственного секторов. Для обеспечения свободной ликвидности, ограниченной пруденциальным регулированием, центральные банки прибегали к политике резервирования (табл. 3).

В развитых странах меньше всего применялась резервная политика. В условиях снижения ликвидности центральные банки выступили в качестве кредитора последней инстанции финансового сектора, расширяя кредитные предложения для поддержания платежеспособности частного нефинансового сектора.

Центральные банки развивающихся стран также проводили политику смягчения условий кредитования, снижая процентную ставку. Валютная и резервная политика играли не последнюю роль в обеспечении финансовой стабильности. В меньшей степени уделялось внимание покупке активов. Проводя гибкую политику, центральные банки сочетали таргетирование инфляции с валютными интервенциями. Рост доверия к центральным банкам, улучшение инфляционных ожиданий, накопление валютных резервов, развитие рынков облигаций в национальной валюте способствовали повышению маневренности денежно-кредитной политики и укреплению финансовой устойчивости развивающихся стран к внешним шокам.

Выводы: Комбинированный шок спроса и предложения, вызванный пандемией коронавируса, оказал резкое влияние на изменение конъюнктуры мирового рынка, выступил катализатором формирования новой экономической реальности, масштабного перелома финансовых трендов в мире. Пандемия Covid-19 стала глобальным шоком, который одновременно повлиял на спрос, предложение и финансовые условия.

Таблица 3. Структурный анализ комплекса мер, предпринимаемых центральными банками различных стран, в \% [6].

\begin{tabular}{|l|c|c|}
\hline \multicolumn{1}{|c|}{ Меры } & Развитые страны & Развиваюиеся страны \\
\hline Кредитные операции & 40 & 35 \\
\hline Покупка активов & 25 & 20 \\
\hline Валютная политика & 15 & 20 \\
\hline Процентная политика & 15 & 15 \\
\hline Резервная политика & 5 & 10 \\
\hline
\end{tabular}


Чтобы стабилизировать финансовые рынки и смягчить снижение экономической активности, центральные банки масштабно и быстро принимали регулятивные меры по поддержанию ликвидности и сдерживанию девальвации на- циональной валюты. Однако затяжной характер мирового локдауна определил необходимость трансформации режимов таргетирования денежно-кредитной политики развивающихся стран для восстановления экономического роста.

\section{Библиографический список}

1. Жукова Д.В., Таркина Н.А., Савинов О.Г. Стабилизация банковского кредитования в условиях тергетирования инфляции // Проблемы развития предприятий: теория и практика. 2020. № 1-1. С. 86-89.

2. Савинов О.Г. Совершенствование институционального и инфраструктурного взаимодействия в процессе кредитования физических лиц // Экономические науки. 2013. № 102. С. 137-141.

3. Савинова Н.Г. Развитие розничной платежной системы на основе единого платежного пространства // Экономические науки. 2011. № 83. С. 177-181.

4. Тиунова М.Г. Влияние внешних шоков на российскую экономику // Финансы: теория и практика. 2018. № 22 (4). C. $146-170$.

5. Annual Report on Exchange Arrangements and Exchange Restrictions 2019 URL: https://www.imf.org/en/ Publications/Annual-Report-on-Exchange-Arrangements-and-Exchange-Restrictions/Issues/2020/08/10/ Annual-Report-on-Exchange-Arrangements-and-Exchange-Restrictions-2019-47102. Accessed: 24.04.2021. (2020).

6. Carlos Cantú, Paolo Cavallino, Fiorella De Fiore and James Yetman.: A global database on central banks' monetary responses to Covid-19. BIS Working Papers No 934. Monetary and Economic Department. March 2021. URL: https://www.bis.org/publ/work934.htm. Accessed: 24.04.2021. (2021).

7. Tershukova M.B., Savinov O. G., Savinova N. G., Milova L. N. TARGETING AS AN INSTRUMENT OF STATE FINANCIAL POLICY IN THE DIGITAL ECONOMY. Advances in Intelligent Systems and Computing (см. в книгах). 2020. T. 908. C. $150-162$. 